\title{
AKT1 NP_001014431.1:p.E17K
}

National Cancer Institute

\section{Source}

National Cancer Institute. AKT1 NP 001014431.1:p.E17K. NCI Thesaurus. Code C98306.

A change in the amino acid residue at position 17 in the RAC-alpha serine/threonine-

protein kinase protein where glutamic acid has been replaced by lysine. 